\title{
ANALISIS POTENSI AGROWISATA UNTUK PENGEMBANGAN EKONOMI LOKAL DI KAMPUNG KURIMAN PANORAMA BARU KOTA BUKITTINGGI
}

\author{
Nana Lili Andriani ${ }^{1}$ \\ Fashbir Noor Sidin ${ }^{2}$ \\ Melinda Noer ${ }^{3}$ \\ Program Studi Perencanaan Pembangunan Universitas Andalas Padang ${ }^{1,2}$ \\ Program Studi Sosial Ekonomi Pertanian Universitas Andalas Padang \\ Penulis Korespondensi e-mail : nanaliliandriani@gmail.com
}

\begin{abstract}
Agrotourism is the most beneficial form of tourism for regional development because it can be used as a strategy for local economic development as well as for the preservation of local natural and cultural resources. With the concept of local economic development, in the formulation of its policy to use the maximum potential of the local potential for agrotourism development. Kuriman Panorama Baru is one of the areas that has long been directed to become an agro-tourism area in the city of Bukittinggi but its development is still very limited so it has not been able to provide economic benefits for the local community. The purpose of this study is to analyze the characteristics and potential that exists as a guide for more operational planning for development actors so that agrotourism can contribute to local economic development. The data analysis method uses descriptive analysis to identify regional characteristics and spatial analysis to see the potential distribution. The results show that Kuriman Panorama Baru has characteristics suitable for agro-tourism development and until now there are still many potentials that can be developed into agro-tourism attractions. Agro-tourism development is directed at a community-based model but still requires serious support from the government and other stakeholders.

Keywords: Agro Tourism, Tourism Potential, Local Economic Development
\end{abstract}

\begin{abstract}
ABSTRAK
Agrowisata merupakan bentuk wisata yang paling menguntungkan bagi pembangunan daerah karena dapat dijadikan strategi untuk pengembangan ekonomi lokal sekaligusuntuk pelestarian sumber daya alam dan budaya setempat. Dengan konsep pengembangan ekonomi lokal maka dalam perumusan kebijakannya memanfaatkan semaksimal mungkin potensi lokal untuk pengembangan agrowisata. Kampung Kuriman Panorama Baru merupakan salah satu daerah yang sudah lama diarahkan menjadi kawasan agrowisata di kota Bukittinggi namun masih sangat terbatas pengembangannya sehingga belum mampu memberikan manfaat ekonomi bagi masyarakat setempat. Tujuan penelitian ini adalah untuk menganalisa karakteristik dan potensi yang ada sebagai pedoman perencanaan yang lebih operasional bagi pelaku pembangunan sehingga agrowisata dapat berkontribusi bagi pengembangan ekonomi lokal. Metode analisis data menggunakan analisis deskriptif untuk mengidentifikasi karakteristik daerah dan analisis spasial untuk melihat sebaran potensi yang ada. Hasil penelitian menunjukkan bahwa Kampung Kuriman Panorama Baru memiliki karakteristik yang cocok bagi pengembangan agrowisata dan hingga saat ini masih banyak potensi yang dapat dikembangkan menjadi daya tarik agrowisata. Pengembangan agrowisata diarahkan dengan model berbasis masyarakat namun tetap membutuhkan dukungan serius dari pemerintah dan stakeholder lainnya.
\end{abstract}

Kata kunci : Agrowisata, Potensi Wisata, Pengembangan Ekonomi Lokal 
Jurnal Planologi Vol. 17 No. 1, April 2020

Available : http://jurnal.unissula.ac.id/index.php/psa

\section{PENDAHULUAN}

Agrowisata memanfaatkan beragam potensi pertanian seperti pemandangan alam, keanekaragaman, kekhasan aktivitas produksi dan teknologi serta budaya masyarakat petaninya menjadi bagian dari rangkaian kegiatan objek wisata (Sastrayuda, 2010). Agrowisata dianggap bentuk wisata alternatif yang lebih menguntungkan karena melibatkan masyarakat lokal sebagai pelaku langsung pariwisata (Nurhidayati, 2013). Pembangunan agrowisata akan menciptakan lapangan pekerjaan baru dan memberikan tambahan penghasilan bagi petani selain hasil produksinya. Selain itu agrowisata juga dapat dijadikan sarana untuk melestarikan sumber daya, melestarikan kearifan dan teknologi lokal (Budiarti, 2013). Penelitian yang dilakukan oleh Jaafar (2013) juga menyimpulkan bahwa agrowisata juga diakui sebagai salah satu cara mempromosikan kekayaan warisan alam dan budaya masyarakat pedesaan. Hal tersebut merupakan alasan kenapa agrowisata sering dikaitkan sebagai suatu upaya untuk pengembangan ekonomi lokal, sekaligus berkontribusi untuk pelestarian alam dan peningkatan aset sosial budaya daerah pedesaan.

Pengembangan ekonomi lokal (PEL) adalah proses dimana pemerintah dan masyarakat lokal bekerjasama untuk merangsang, mendorong dan memelihara aktivitas usaha dalam rangka penciptaan lapangan pekerjaan (Blakely, 1994). Menurut Munir (2017) konsep ini merupakan upaya untuk penguatan daya saing ekonomi lokal sehingga berdampak bagi peningkatan kesejahteraan masyarakat setempat. Teori PEL sendiri mengemukakan bagaimana mengembangkan perekonomian lokal dengan memanfaatkan potensi sumber daya yang dimiliki, sejauh mana industri tersebut berperan menciptakan lapangan kerja bagi masyarakat setempat serta bagaimana untuk keberlanjutannya dimasa depan (Blair, 1995). Jadi konsep dalam pengembangan ekonomi lokal menekankan pada bagaimana merumuskan kebijakan dalam rangka pengembangan potensi semaksimal mungkin dengan menggunakan aspek lokalitas dalam pembangunan.

Pada penelitian ini potensi yang dimaksud berupa kekayaan sumber daya alam serta budaya manusia yang dapat dikembangkan sebagai objek agrowisata dan atraksi pariwisata pendukung. Kekayaan sumber daya alam dan budaya ini membuat suatu kawasan berpotensi kuat untuk memenuhi permintaan pasar wisata (Kementerian Pariwisata, 2015). Potensi yang dimiliki oleh suatu kawasan dapat dianalisis melalui karakteristik alam dan masyarakat pada lokasi tersebut sebab masing-masing kawasan mempunyai karakteristik yang berbeda antara satu dengan yang lain (Karampela S, et al, 2019). Selanjutnya melalui 
pemetaan dapat diperlihatkan sebaran objek wisata yang sudah ada maupun potensi yang dapat berkembang menjadi daya tarik agrowisata.

Analisis potensi merupakan hal yang mendasar dalam menyusun sebuah perencanaan pembangunan agar lebih operasional sesuai dengan kondisi dan permasalahan serta tidak menyebabkan tumpang tindih kegiatan yang justru melemahkan kawasan tersebut. Pentingnya menganalisa karakteristik dan potensi wisata di tekankan oleh Aulya (2016) bahwa seringkali kegagalan dalam pengembangan wisata perdesaan termasuk agrowisata karena selama ini pengambilan keputusan bersifat topdown, sehingga pembangunan tidak berdasarkan potensi SDA dan SDM yang ada didaerah tersebut. Selain itu juga analisis ini bertujuan agar dalam pembangunannya, agrowisata dapat diarahkan dengan mengoptimalkan sumberdaya yang ada dan dapat memberikan manfaat berlanjutan bagi pengembangan ekonomi lokal tanpa meninggalkan dampak negatif bagi lingkungan dan budaya setempat. Perencanaan yang berbasis pada potensi suatu kawasan dapat memberikan arahan bagi para pelaku pembangunan sehingga terwujud proses pembangunan wisata yang terpadu, bersinergi dan saling menunjang.

Kota Bukittinggi merupakan daerah tujuan wisata utama di Provinsi Sumatera Barat disamping sebagai kota pendidikan, kota pelayanan kesehatan, kota perdagangan dan jasa serta tempat peristirahatan. Keindahan alam, kekayaan budaya, peninggalan sejarah, kuliner menjadi potensi Kota Bukittinggi yang menarik para wisatawan asing untuk berkunjung ke Kota Bukittinggi. Sektor pariwisata merupakan penyumpang terbesar bagi Pendapatan Asli Daerah (PAD) Kota Bukittinggi. Total PAD dari sektor ini selama tahun 2018 sebesar Rp.37.771.424.853,- dan jauh lebih besar dibandingkan tahun sebelumnya 2017 yaitu Rp. 33.820.740.960,- (Badan Keuangan, 2018). Seluruh subsektor industri pariwisata yang terdapat pada PDRB yaitu perhotelan, restoran, penunjang angkutan umum dan sektor hiburan dan rekreasi merupakan basis ekonomi dan memberikan peranan yang besar terhadap perekonomian Kota Bukittinggi (Amelia, 2012). Data BPS 2019 menunjukkan kontribusi subsektor industri pariwisata terhadap produk domestik regional bruto (PDRB) Kota Bukittinggi sebagai berikut :

Tabel 1. Kontribusi Subsektor Industri Pariwisata Terhadap PDRB Kota Bukittinggi

\begin{tabular}{ccccccc}
\hline Tahun & $\begin{array}{c}\text { Transportasi } \\
\text { dan } \\
\text { Pergudangan }\end{array}$ & $\begin{array}{c}\text { Penyediaan } \\
\text { Akomodasi } \\
\text { dan Makan } \\
\text { Minum }\end{array}$ & $\begin{array}{c}\text { Jasa } \\
\text { Lainnya }\end{array}$ & Jumlah & PDRB & $\begin{array}{c}\text { Kontribusi } \\
\text { Subsektor } \\
\text { Pariwisata } \\
\text { (\%) }\end{array}$ \\
\hline 2014 & $617,352.39$ & $277,747.52$ & $217,786.15$ & $1,112,886.06$ & $5,635,927.99$ & 19.75 \\
\hline 2015 & & & & & & \\
\hline
\end{tabular}

Nana Lili Andriani, Fashbir Noor Sidin, Melinda Noer I 52 Analisis Potensi Agrowisata Untuk Pengembangan ... 
Jurnal Planologi Vol. 17 No. 1, April 2020

\begin{tabular}{rrrrrrrr}
\hline Tahun & $\begin{array}{c}\text { Transportasi } \\
\text { dan } \\
\text { Pergudangan }\end{array}$ & $\begin{array}{c}\text { Penyediaan } \\
\text { Akomodasi } \\
\text { dan Makan } \\
\text { Minum }\end{array}$ & $\begin{array}{c}\text { Jasa } \\
\text { Lainnya }\end{array}$ & Jumlah & PDRB & $\begin{array}{c}\text { Kontribusi } \\
\text { Subsektor } \\
\text { Pariwisata } \\
\text { (\%) }\end{array}$ \\
\hline & $665,354.45$ & $334,075.06$ & $238,891.06$ & $1,238,320.57$ & $6,169,750.95$ & \\
\hline 2016 & $719,657.59$ & $389,102.14$ & $266,559.93$ & $1,375,319.66$ & $6,783,086.09$ & 20.28 \\
\hline 2017 & $799,518.90$ & $433,068.27$ & $285,548.92$ & $1,518,136.09$ & $7,453,106.84$ & 20.37 \\
\hline & & & & & & \\
2018 & $874,304.60$ & $482,068.27$ & $318,623.82$ & $1,674,996.69$ & $8,068,881.71$ & 20.76 \\
\hline Sumber: $B P S, 2019$ & & & & & \\
\hline
\end{tabular}

Kampung Kuriman Panorama Baru adalah salah satu daerah di Kota Bukittinggi dengan pemandangan alam yang indah dan dikelilingi oleh barisan bukit dan ngarai. Di daerah ini terdapat lahan pertanian yang luas sehingga mendukung bagi pengembangan agrowisata dan saat ini juga sudah terdapat beberapa objek wisata. Walaupun menjadi bagian dari kota wisata tidak membuat objek wisata di sini sama populernya dengan objek wisata lain di Kota Bukittinggi padahal pencanangan Kampung Kuriman Panorama Baru sebagai kawasan agrowisata sudah dimulai sejak lama yaitu pada awal pembukaan Taman Panorama Baru sekitar tahun 1950an.

Pengembangan agrowisata di kawasan ini ditujukan untuk mengembangkan ekonomi masyarakatnya. Agrowisata diharapkan akan memberikan manfaat seperti membuka lapangan pekerjaan dan timbulnya usaha mandiri, namun pengembangan wisata di daerah ini masih sangat terbatas. Saat ini objek wisata yang ada hanya Taman Panorama Baru sedangkan untuk agrowisata yang dikembangkan oleh masyarakat adalah Agrowisata salak Indosiar dan Rumah Sehat dan Taman Bacaan Mutiara Hati. Ketiga objek wisata yang dikelola secara swadaya oleh masyarakat/pemilik lahan dan menjadi icon wisata di kawasan Panorama Baru ini belum bisa memberikan manfaat ekonomi seperti membuka lapangan pekerjaan baru ataupun memberikan tambahan pendapatan bagi masyarakat disekitarnya. Kampung Kuriman Panorama Baru bahkan termasuk dalam daerah binaan Dinas Pemberdayaan Perempuan dan Keluarga Berencana Kota Bukittinggi dalam program Kampung KB Tahun 2016 dengan indikator penetapannya tingkat kesejahteraan masyarakat di daerah ini lebih rendah dibandingkan daerah lain di Kota Bukittinggi 


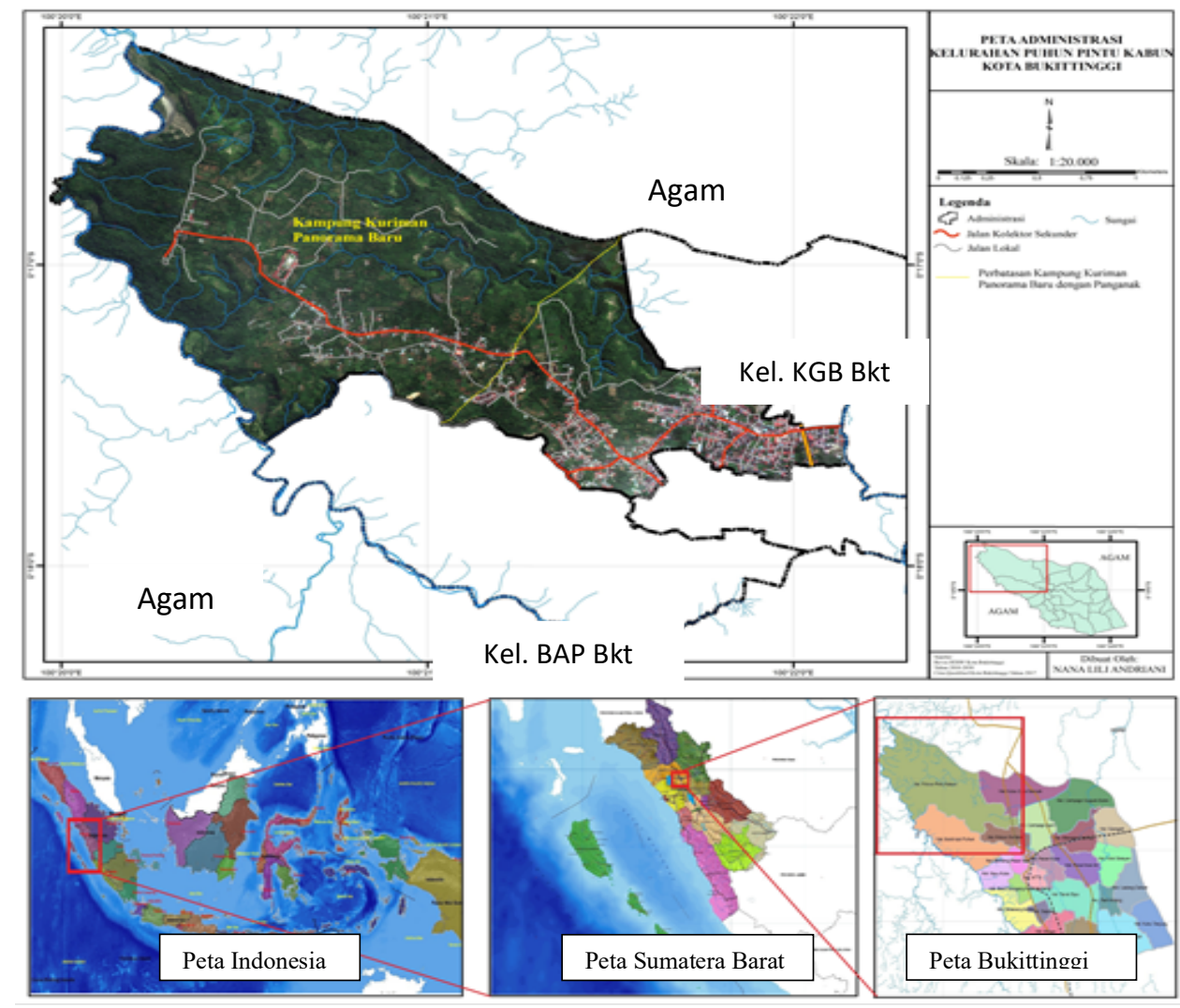

Gambar 1. Peta Administrasi Kampung Kuriman Panorama Baru Kota Bukittinggi Sumber : Hasil Olahan, 2019

Masih terbatasnya pengembangan yang telah dilakukan kiranya masih sangat mungkin untuk ditemukan potensi wisata lain yang memiliki daya tarik. Oleh karena itu diperlukan perencanaan pembangunan yang lebih matang untuk mengembangkan daerah ini agar kedepannya dapat memberikan manfaat bagi perekonomian masyarakatnya. Sebagai masukan bagi perencanaan pembangunan di daerah ini diperlukan penelitian awal untuk mengidentifikasi dan menganalisis potensi agrowisata sekaligus menentukan arah pengembangan agrowisata di kawasan Panorama Baru Kota Bukittinggi.

\section{METODOLOGI}

Penelitian ini merupakan penelitian kualitatif dengan menggunakan 2 jenis data yaitu data primer dan data sekunder. Teknik pengumpulan data primer dilakukan dengan dua cara, yaitu observasi lapangan dan wawancara. Wawancara dilakukan kepada masyarakat menggunakan teknik wawancara insidensial, sedangkan kepada pengerak pariwisata di Panorama Baru dilakukan dengan teknik snow ball. Sementara pengumpulan 
data sekunder menggunakan studi literatur yang didapat melalui dokumen atau catatan mengenai Kampung Kuriman Panorama Baru.

Teknik analisis data yang digunakan yaitu deskriptif dan spasial. Analisis deskriptif dilakukan untuk menganalisa karakteristik dengan mengkomparasikan kondisi eksisting berdasarkan survey primer sesuai topik penelitian. Analisis spasial dilakukan sebagai dasar pemetaan untuk memeperlihatkan sebaran objek wisata di Panorama Baru. Hasil kedua analisis akan menjadi arahan pengembangan agrowisata di Daerah Panorama Baru.

Analisis karakteristik daerah Panorama Baru akan dilakukan pada tiap topik sebagaimana terlampir pada tabel 2 dibawah ini :

Tabel 2. Variabel dan indikator penelitian karakteristik daerah Kampung Kuriman Panorama Baru

\begin{tabular}{|c|c|c|}
\hline \multicolumn{2}{|l|}{ Variabel } & \multirow{2}{*}{ Indikator } \\
\hline \multirow{10}{*}{$\begin{array}{l}\text { A. Fisik/ } \\
\text { Lingkungan/ } \\
\text { Insfrastuktur }\end{array}$} & 1) & \\
\hline & 2) & $\begin{array}{l}\text { Ketersediaan Objek dan Daya Tarik Wisata (ODTW) lain di sekitar } \\
\text { kawasan agrowisata }\end{array}$ \\
\hline & 3) & Rute perjalanan untuk menghubungkan agrowisata dengan ODTW \\
\hline & 4) & $\begin{array}{l}\text { Transportasi berupa angkutan umum ataupun angkutan khusus yang } \\
\text { disediakan masyarakat lokal }\end{array}$ \\
\hline & 5) & $\begin{array}{l}\text { Pusat penjualan makanan / oleh }- \text { oleh hasil agrowisata yang } \\
\text { disediakan masyarakat lokal }\end{array}$ \\
\hline & 6) & Penginapan untuk wisatawan yang disediakan masyarakat lokal \\
\hline & 7) & $\begin{array}{l}\text { Fasilitas penunjang seperti musholla, toilet, dan tempat parkir yang } \\
\text { disediakan masyarakat lokal }\end{array}$ \\
\hline & 8) & Jaringan air bersih untuk mendukung kegiatan agrowisata \\
\hline & 9) & Jaringan listrik untuk mendukung kegiatan agrowisata \\
\hline & 10) & Sistem persampahan untuk mendukung kegiatan agrowisata \\
\hline \multirow[t]{3}{*}{ B. Ekonomi } & 1) & $\begin{array}{l}\text { Mata pencaharian mayoritas masyarakat sebagai pendukung } \\
\text { agrowisata }\end{array}$ \\
\hline & 2) & Pendidikan masyarakat sebagai pelaku agrowisata \\
\hline & 3) & Produk unggulan yang dihasilkan daerah \\
\hline \multirow{5}{*}{$\begin{array}{ll}\text { C. } & \text { Sosial } \\
& \text { Budaya }\end{array}$} & 1) & Kemampuan masyarakat lokal sebagai tour guide agrowisata \\
\hline & 2) & $\begin{array}{l}\text { Program pemberdayaan guna meningkatkan kapasitas kepariwisataan } \\
\text { masyarakat lokal }\end{array}$ \\
\hline & 3) & Produk wisata yang khas sesuai karakteristik masyarakat lokal \\
\hline & 4) & Pertunjukkan budaya masyarakat lokal sebagai daya tarik \\
\hline & 5) & $\begin{array}{l}\text { Jenis kegiatan yang dapat dilakukan seperti menanam, memetik, dan } \\
\text { mengolah hasil agrowisata }\end{array}$ \\
\hline \multirow[t]{3}{*}{ D. Kelembagaan } & 1) & Dukungan kebijakan dan peraturan dari pemerintah \\
\hline & 2) & Promosi pengembangan agrowisata yang dilakukan pemerintah \\
\hline & 3) & $\begin{array}{l}\text { Keberadaan Kelompok Sadar Wisata sebagai stakeholder agrowisata } \\
\text { yang membantu masyarakat lokal }\end{array}$ \\
\hline
\end{tabular}

Sumber: Puspito A R et al (2015) ; (Juwita, 2017) diolah, 2019

Untuk pemetaan akan dibedakan dengan kelompok objek wisata yang sudah ada dan potensi yang dapat dikembangkan menjadi daya tarik agrowisata dengan kategori potensi alam, pertanian, budaya dan aktivitas yang bisa dilakukan di kawasan agrowisata. 
Jurnal Planologi Vol. 17 No. 1, April 2020

Available : http://jurnal.unissula.ac.id/index.php/psa

\section{HASIL DAN PEMBAHASAN}

\subsection{Karakteristik Kawasan Panorama Baru}

Berdasarkan analisis karateristik diketahui aspek mana saja yang terpenuhi dan tidak terpenuhi pada daerah Panorama Baru dengan hasil sebagai berikut :

A. Ditinjau dari aspekfisik/lingkungan/insfrastruktur

Kampung Kuriman Panorama Baru ini terletak pada daerah paling utara diujung Kota Bukittinggi. Secara administrasi daerah ini merupakan RW 01 pada Kelurahan Puhun Pintu Kabun Kecamatan Mandiangin Koto Selayan. Kampung Kuriman Panorama Baru merupakan daerah yang dikelilingi bukit, lembah dan ngarai yang membuat daerah ini mempunyai iklim yang masih sejuk dan panorama alam yang indah. Daerah ini berada pada ketinggian $+780-950$ meter di atas permukaan laut dan terletak pada posisi $100^{\circ} 20^{\prime}-$ $100^{\circ} 22^{\prime}-$ Bujur Timur dan $00^{\circ} 16^{\prime}-00^{\circ} 18^{\prime}$ Lintang Selatan. Luas wilayah Kampung Kuriman Panorama Baru adalah $+3.27 \mathrm{Km} 2$, yang merupakan 13 \% luas Kota Bukittinggi. Luas Kampung Kuriman ini bahkan lebih luas dari kelurahan lain di Kota Bukittinggi. Jarak Kampung Kuriman Panorama Baru dengan pusat Kota Bukittinggi cukup dekat yaitu $+5,2 \mathrm{~km}$ dengan perkiraan waktu tempuh dengan kendaraan bermotor sekitar 10 menit.

Pemandangan alam Panorama Baru mempunyai pesona yang akan menjadi daya tarik pariwisata yaitu Panorama alam, ngarai, hamparan kebun buah dan sayuran juga tanaman palawija. Udara di daerah ini juga masih sangat bersih dan sejuk sebab daerah ini terletak disudut kota Bukittinggi yang tidak dilalui oleh jalur lintas karena merupakan jalan buntu. Di daerah ini juga masih banyak lahan kosong yang belum digarap oleh masyarakatnya. Sebagian besar lahan di Kampung Kuriman digunakan untuk perkebunan, ladang dan lahan persawahan bagi masyarakat lokal yaitu sekitar 1,27 km2 atau $38.9 \%$ dari luas Kampung Kuriman Panorama Baru juga merupakan 5.05 \% dari luas Kota Bukittinggi. Rincian penggunaan lahan di Kampung Kuriman Panorama Baru ini dapat dilihat dari tabel dibawah ini.

Tabel 3. Rincian Penggunaan Lahan Kampung Kuriman Kota Bukittinggi

\begin{tabular}{clcc}
\hline No & Pengunaan Lahan & Luas m2 & $\%$ \\
\hline 1 & Tanah Kosong & 275,543 & 8.41 \\
\hline 2 & Pasir/Bukit Pasir & 1,205 & 0.037 \\
\hline 3 & Semak Belukar & 861,745 & 26.29 \\
\hline 4 & Perkebunan & 988,079 & 30.14 \\
\hline 5 & Sawah & 19,307 & 0.59 \\
\hline
\end{tabular}

Nana Lili Andriani, Fashbir Noor Sidin, Melinda Noer I 56 Analisis Potensi Agrowisata Untuk Pengembangan ... 
Jurnal Planologi Vol. 17 No. 1, April 2020

\begin{tabular}{|c|c|c|c|}
\hline No & Pengunaan Lahan & Luas m2 & $\%$ \\
\hline 6 & Ladang & 267,509 & 8.16 \\
\hline 7 & Air Tawar Sungai & 21,734 & 0.66 \\
\hline 8 & Pemukiman dan Tempat Kegiatan & 88,818 & 2.71 \\
\hline 9 & Pemakaman Umum & 1,268 & 0.04 \\
\hline 10 & Stadion Olah Raga & 785 & 0.02 \\
\hline 11 & Hutan & 751,934 & 22.94 \\
\hline Total & & $3,277,927$ & 100.00 \\
\hline
\end{tabular}

Sumber : RTRW Kota Bukittinggi, 2019

Ketersediaan objek daya tarik wisata lain di sekitar agrowisata cukup lengkap, sehingga banyak objek wisata yang akan mendukung kemajuan agrowisata. Rute dan jaringan jalan untuk roda 4 yang saat ini hanya ada di jalan utama dan lintas kiri sedangkan untuk lintas bagian kanan hanya tersedia jalan tanah yang biasa digunakan petani menuju kebunnya. Untuk model transportasi pun saat ini hanya ada angkutan umum dengan rute jalan utama tanpa melalui titik-titik sebaran objek wisata.

Ketersediaan infrastruktur dikawasan wisata Panorama Baru ini masih sangat minim. Objek yang telah ada seperti Taman Panorama Baru dan Agrowisata Indosiar belum memiliki jaringan air bersih dan listrik, pusat kuliner dan fasilitas penunjang lain seperti mushola, toilet. Sedangkan di Rumah Sehat memiliki fasilitas yang lebih lengkap karena memang berlokasi di rumah pemilik bahkan di sini juga tersedia fasilitas seperti rumah singgah untuk wisatawan.

B. Ditinjau dari aspek ekonomi

Tingkat pendidikan masyarakat Kampung Kuriman Panorama Baru masih tergolong rendah, bahkan untuk saat ini saja masih ada 16 orang anak yang putus sekolah yang terdata di daerah tersebut. Sebagian besar pendidikan masyarakat berada pada tingkat tamat SLTA/sederajat yaitu sebanyak 387 orang $(24,49 \%)$, kemudian yang belum/tidak sekolah sebanyak 325 orang (20,57\%), masyarakat yang menamatkan SD/sederajat sebanyak 320 orang atau $20.25 \%$ dan tidak tamat SD sebesar 14,62\% yaitu 231 orang. Untuk lebih rincinya data tingkat pendidikan masyarakat ini dapat dilihat pada tabel 4.

Tabel 4. Data Tingkat Pendidikan Masyarakat Kampung Kuriman Panorama Baru

\begin{tabular}{clcccc}
\hline No & Tingkat Pendidikan & $\begin{array}{c}\text { Laki-laki } \\
\text { (jiwa) }\end{array}$ & $\begin{array}{c}\text { Perempuan } \\
\text { (jiwa) }\end{array}$ & Jumlah & (\%) \\
\hline 1 & Tidak/Belum Sekolah & 165 & 160 & 325 & 20.57 \\
\hline $\begin{array}{l}\text { Tidak/Belum Tamat SD } \\
\text { /sederajat }\end{array}$ & 124 & 107 & 231 & 14.62 \\
\hline
\end{tabular}


Jurnal Planologi Vol. 17 No. 1, April 2020

\begin{tabular}{cccccc}
\hline No & Tingkat Pendidikan & $\begin{array}{c}\text { Laki-laki } \\
\text { (jiwa) }\end{array}$ & $\begin{array}{c}\text { Perempuan } \\
\text { (jiwa) }\end{array}$ & Jumlah & $\mathbf{( \% )}$ \\
\hline 3 & Tamat SD/Sederajat & 158 & 162 & 320 & 20.25 \\
\hline 4 & Tamat SLTP/Sederajat & 109 & 79 & 188 & 11.90 \\
\hline 5 & Tamat SLTA /Sederajat & 191 & 196 & 387 & 24.49 \\
\hline 6 & Tamat D I D II & 1 & 10 & 11 & 0.70 \\
\hline 7 & Tamat D III/ Sederajat & 13 & 20 & 33 & 2.09 \\
\hline 8 & Tamat D IV/S1 & 37 & 45 & 82 & 5.19 \\
\hline 9 & Tamat S2 & 2 & 1 & 3 & 0.33 \\
\hline & Jumlah & $\mathbf{8 0 0}$ & $\mathbf{7 8 0}$ & $\mathbf{1 , 5 8 0}$ & $\mathbf{1 0 0}$ \\
\hline
\end{tabular}

Sumber : Data Dinas Kependudukan dan Pencatatan Sipil Kota Bukittinggi, September 2019

Untuk data pekerjaan masyarakat di kampung Kuriman Panorama Baru ini dapat dilihat pada tabel 5 dibawah.

Tabel 5. Data Pekerjaan Masyarakat Kampung Kuriman Panorama Baru

\begin{tabular}{llcccr}
\hline No. & Pekerjaan & $\begin{array}{c}\text { Laki - laki } \\
\text { ( jiwa) }\end{array}$ & $\begin{array}{c}\text { Perempuan } \\
\text { (jiwa) }\end{array}$ & Jumlah & $\begin{array}{c}\text { Persentase } \\
(\mathbf{\%})\end{array}$ \\
\hline 1 & ASN & 24 & 21 & 45 & 2.85 \\
\hline 2 & Tenaga Pengajar & 2 & 18 & 20 & 1.27 \\
\hline 3 & Wiraswasta & 322 & 81 & 403 & 25.51 \\
\hline 4 & Petani & 48 & 29 & 77 & 4.87 \\
\hline 5 & Pelajar/Mahasiswa & 205 & 181 & 386 & 24.43 \\
\hline 6 & Tenaga Kesehatan & 2 & 4 & 6 & 0.38 \\
\hline 7 & Pensiunan & 16 & 6 & 22 & 1.39 \\
\hline 8 & Lainnya & 0 & 277 & 277 & 17.53 \\
\hline 9 & Belum/Tidak bekerja & 181 & 163 & 344 & 21.77 \\
\hline & Jumlah & $\mathbf{8 0 0}$ & $\mathbf{7 8 0}$ & $\mathbf{1 , 5 8 0}$ & $\mathbf{1 0 0 . 0 0}$ \\
\hline
\end{tabular}

Sumber : Data Dinas Kependudukan dan Pencatatan Sipil Kota Bukittinggi, September 2019

Walaupun rata-rata setiap keluarga di daerah ini mempunyai lahan perkebunan/pekarangan yang luas, namun hanya $4,87 \%$ orang masyarakatnya yang menjadikan pertanian sebagai pekerjaan utamanya, itupun dengan usia rata-rata 50 tahun ke atas. Masyarakat yang berprofesi sebagai petani adalah masyarakat dengan ekonomi rata-rata menengah ke bawah dengan pendidikan rata-rata SD dan SMP. Sebagian besar masyarakat lainnya bertani hanya untuk pekerjaan tambahan dan lebih memilih berwiraswasta seperti berdagang atau menjadi kuli bangunan dan pekerjaan serabutan lainnya sebab saat ini mereka belum bisa mengoptimalkan hasil pertanian untuk memenuhi kebutuhan sehari-hari. Padahal dengan dikembangkannya agrowisata didaerah ini akan 
membawa dampak positif bagi ekonomi masyarakatnya seperti membuka lapangan pekerjaan barudan lain-lain.

C. Ditinjau dari aspek sosial dan budaya

Budaya masyarakat di daerah ini belum tinggi cenderung pasif. Mereka akan bergerak hanya jika dimotivasi dengan contoh daerah lain yang telah sukses. Kemampuan masyarakat sebagai tour guide masih terbatas dan sampai saat ini belum ada program pemberdayaan masyarakat yang bertujuan meningkatkan kapasitas kepariwisataan masyarakat lokal. Untuk produk agrowisata sendiri sudah sesuai dengan potensi yang ada yaitu produk yang berbasis pertanian.

Pertunjukan seni budaya dan jenis kegiatan di objek wisata perlu peningkatan karena masih bisa dikembangkan sesuai potensi yang ada. Apalagi untuk di kawasan Taman Panorama yang saat ini hanya menawarkan rumah pohon sebagai spot foto. Jika ditambahkan kegiatan lain yang membuat wisatawan lebih lama berkunjung dan menetap maka akan manfaat yang dapat diterima masyarakat.

D. Ditinjau dari aspek kelembagaan

Kebijakan Pemerintah untuk menjadikan daerah Panorama Baru menjadi ruang terbuka hijau dan taman kota sesuai RTRW Tahun 2017 menjadi modal awal bagi pengembangan agrowisata namun untuk program pengembangan wisata bisa dikatakan tidak ada. Saat ini untuk daerah Panorama Baru belum ada pembentukan Kelompok Sadar Wisata. Untuk promosi wisata umumnya dilakukan oleh swadaya masyarakat ataupun individu.

\subsection{Pemetaan Potensi Agrowisata di Panorama Baru}

Untuk potensi daerah dapat dibedakan menjadi dua yaitu objek wisata yang sudah ada dan potensi yang dapat dikembangkan menjadi daya tarik agrowisata. Analisis potensi tersebut disajikan pada Tabel 6 dibawah ini :

Tabel 6. Pengelompokan Objek dan Potensi Pengembangan Agrowisata di Kampung Kuriman Panorama Baru

\begin{tabular}{lccc}
\hline & Kategori & Objek wisata yang sudah ada & $\begin{array}{c}\text { Potensi yang dapat } \\
\text { dikembangkan }\end{array}$ \\
\hline A. $\quad$ Alam & $\bullet$ & Taman Panorama Baru. & $\bullet$ Ngarai Panorama. \\
\hline
\end{tabular}




\begin{tabular}{|c|c|c|}
\hline Kategori & Objek wisata yang sudah ada & $\begin{array}{l}\text { Potensi yang dapat } \\
\text { dikembangkan }\end{array}$ \\
\hline $\begin{array}{cl}\text { B. } & \text { Pertanian } \\
\text { 1) } & \text { Tanaman Pangan } \\
\text { 2) } & \text { Pertanian } \\
\text { 3) } & \text { Perternakan }\end{array}$ & $\begin{array}{ll}\text { - } & \text { Agrowisata } \\
\text { Indosiar }\end{array}$ & $\begin{array}{ll}\text { - } & \text { Kebun Sayur-sayuran } \\
\text { - } & \text { Kebun Buah-buahan } \\
\text { - } & \text { Budidaya Tanaman hias } \\
\text { - } & \text { Peternakan kelinci } \\
\text { - } & \text { Peternakan Kambing perah } \\
\text { - } & \text { Peternakan Sapi }\end{array}$ \\
\hline $\begin{array}{l}\text { C. Budaya } \\
\text { 1) Kesenian } \\
\text { 2) Kuliner }\end{array}$ & - $\quad$ Saluang & $\begin{array}{l}\text { Kesenian } \\
\text { - Rantai } \\
\text { - Tari Daerah } \\
\text { Kuliner } \\
\text { - Jajanan tradisional seperti } \\
\text { ripik pisang, tumbang, } \\
\text { lapek pisang, lapek ubi, } \\
\text { kerupuk taleh }\end{array}$ \\
\hline D. Aktivitas & $\begin{array}{l}\text { - Wisata Edukasi di } \\
\text { Rumah Sehat dan } \\
\text { Taman Bacaan Mutiara } \\
\text { Hati } \\
\text { - Wisata Berburu Babi } \\
\text { - Lintas alam }\end{array}$ & $\begin{array}{ll}\text { - } & \text { Camping } \\
\text { - } & \text { Outbond } \\
\text { - } & \text { Sepeda Santai } \\
\text { - } & \text { Berkuda } \\
\text { - } & \text { Memetik dan mengolah } \\
& \text { hasil pertanian } \\
\text { - } & \text { Turbing } \\
\text { - } & \text { Body Rafting } \\
\end{array}$ \\
\hline
\end{tabular}

Sumber : Hasil penelitian di lapangan, 2019

Sebaran lokasi objek wisata yang sudah ada dapat dilihat melalui peta dibawah ini :

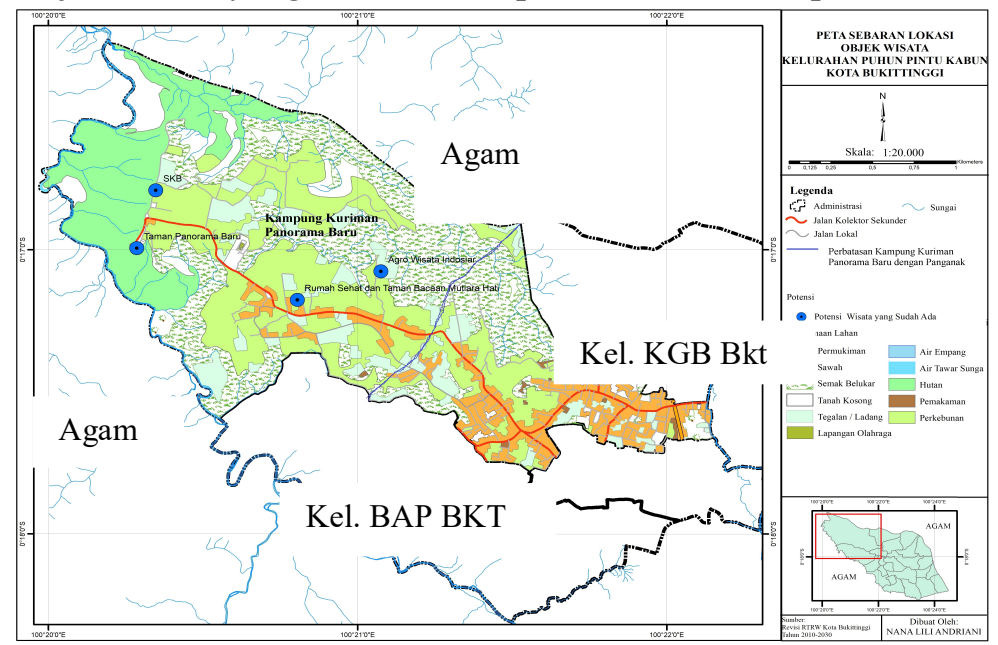

Gambar 2. Sebaran Objek Wisata Di Kampung Kuriman Panorama Baru Sumber : Revisi RTRW Kota Bukit Tinggi 2010-2030, Hasil Analisis, 2019

Untuk sebaran potensi pengembangan dapat dilihat pada gambar 3 dibawah ini : 
Jurnal Planologi Vol. 17 No. 1, April 2020

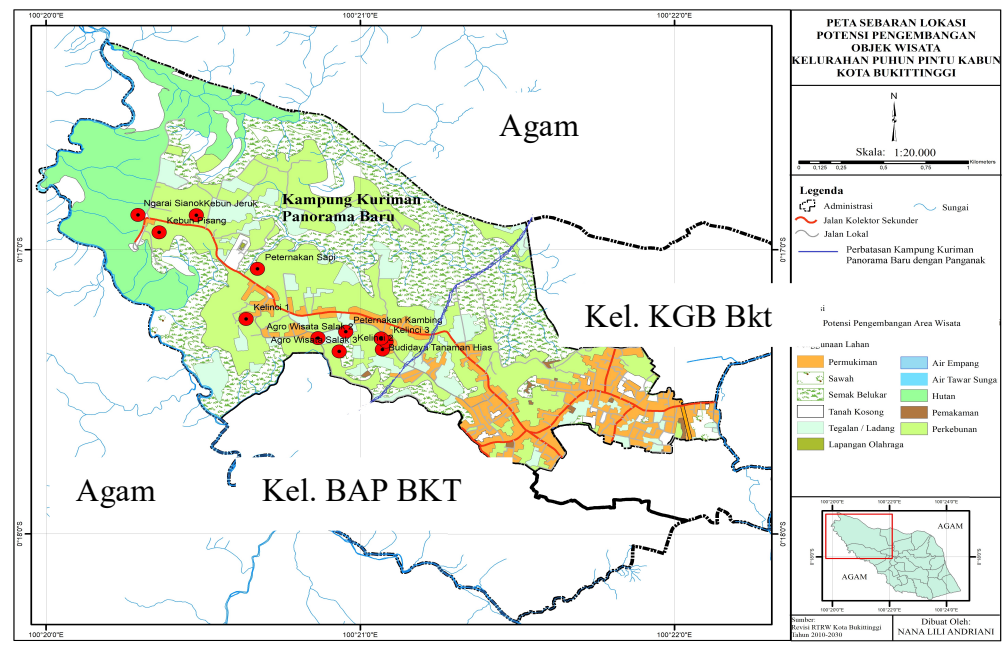

Gambar 3. Sebaran Potensi Pengembangan Agrowisata Di Kuriman Panorama Baru Sumber : Revisi RTRW Kota Bukit Tinggi 2010-2030, Hasil Analisis, 2019

\subsection{Arah Pengembangan Agrowisata Panorama Baru}

Sebagai gambaran awal untuk inventarisasi dan analisis sebaran potensi pariwisata di Panorama Baru dapat terlihat pada gambar 4 di bawah ini.:

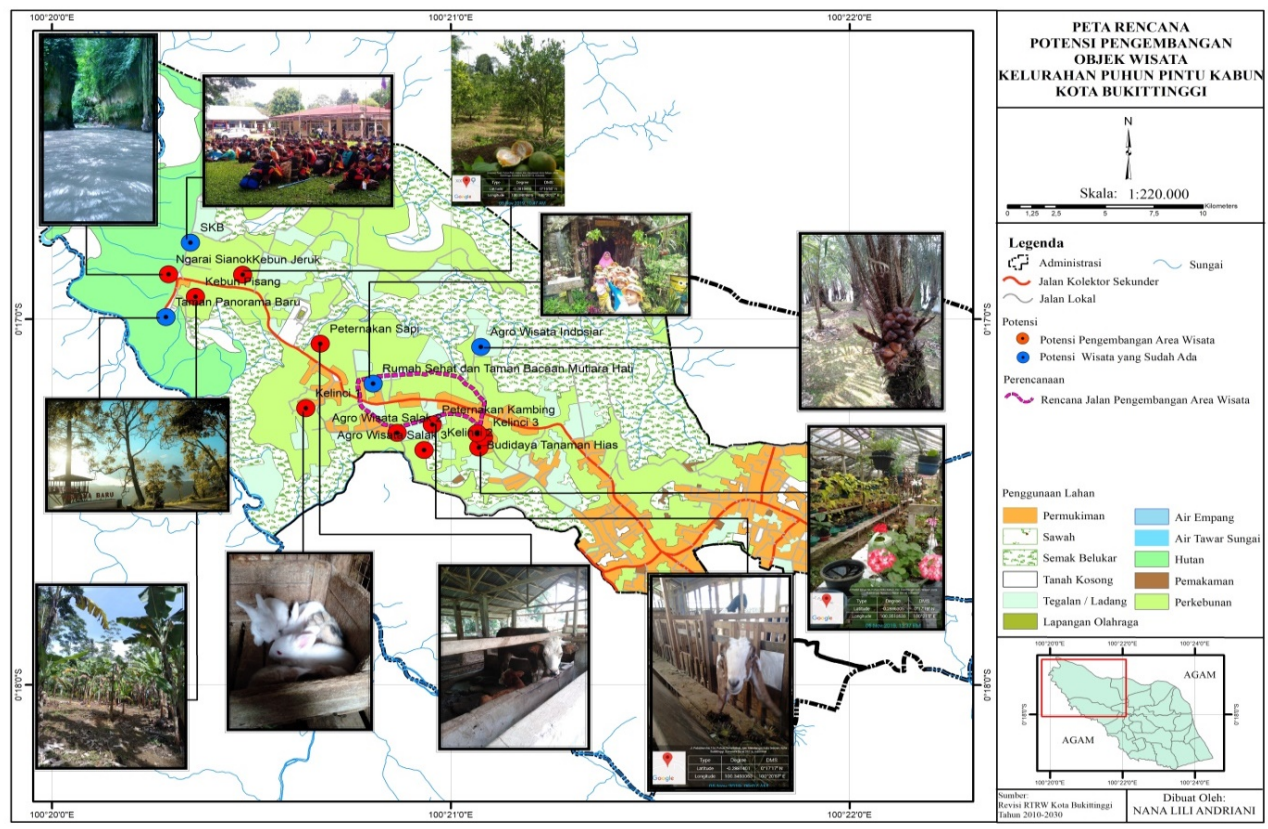

Gambar 4. Rencana Pengembangan Objek Agrowisata di Kampung Kuriman Panorama Baru Sumber : Revisi RTRW Kota Bukit Tinggi 2010-2030, Hasil Analisis, 2019

Adapun kelompok objek wisata yang dapat ditawarkan di daerah Panorama Baru terdiri atas :
A. Wisata Alam
1) Taman Panorama Baru 
Jurnal Planologi Vol. 17 No. 1, April 2020

Taman Panorama Baru merupakan objek wisata utama dan andalan di daerah ini. Taman ini dibangun diatas lahan milik ulayat/kaum dan berdasarkan wawancara yang dilakukan pada tokoh masyarakat di daerah tersebut diperkirakan dibuka sekitar tahun 1950an. Taman Panorama Baru ini memiliki view alam yang berupa pemandangan Gunung Merapi dan Gunung Singgalang, barisan bukit yang indah serta lembah dan ngarai yang berkelok. Panorama Baru juga memiliki tingkat keragaman flora dan fauna yang cukup tinggi. Berbagai jenis flora tumbuh baik di areal kawasan maupun daerah aliran sungai dan jurang. Selain itu, di wilayah ini juga terdapat beberapa jenis satwa seperti monyet atau kera juga anekaragam jenis kupu-kupu. Sejak dibangun satu-satunya daya tarik dari taman ini hanya pemandangan alam dan minim pengembangan lainnya. Hal ini berdampak kepada kurang populernya taman ini oleh wisatawan yang berkunjung ke Kota Bukittinggi sehingga objek ini seakan mati suri. Baru pada pertengahan tahun 2018 objek wisata ini dikembangkan oleh pemuda pemudi daerah dengan membangun rumah pohon mengunakan dana manunggal tahun 2018 sebagai daya tarik pengunjung. Seakan bangun dari tidur panjang dengan adanya rumah pohon tadi pada libur lebaran $1439 \mathrm{H}$ tingkat kunjungan ke Taman Panorama Baru mencapai angka 400 orang setiap hari padahal diharihari sebelumnya tingkat kunjungan sangat rendah bahkan tidak ada kunjungan sama sekali. Wisatawan yang datang tidak hanya berasal dari dalam Kota Bukittinggi tetapi juga dari luar daerah.

Kondisi tersebut tidak bisa bertahan lama. Kurangnya keseriusan pihak terkait dalam pengelolaan membuat saat ini rumah pohon yang ada tidak terawat dengan baik dan Taman Panorama Baru kembali menyepi di sudut Kota Bukittinggi. Masyarakat perlu membuat pengembangan dan inovasi baru untuk menarik wisatawan agar mau berkunjung di kawasan wisata ini. Upaya pengembangan selanjutnya yang dapat dilakukan bisa dengan menawarkan spot foto baru yang unik namun tidak merusak tatanan alam. Dalam rangka menambah lama waktu kunjungan, dikawasan ini juga bisa ditawarkan atraksi wisata seperti sepeda santai dan berkuda. Selain itu dikawasan ini juga bisa dibangun outbond seperti flying fox, halang rintang dan sejenisnya. Hal ini tentunya akan menjadi daya tarik sendiri bagi pengunjung mengingat nantinya lokasi ini akan menjadi area outbond dengan alam yang indah satu-satunya di Kota Bukittinggi. Pengelola juga bisa melakukan kerjasama dengan pihak pemerintah daerah, bank-bank atau perusahaan yang akan melaksanakan kegiatan seperti family gathering dilokasi ini. Dengan adanya 
Jurnal Planologi Vol. 17 No. 1, April 2020

pengembangan pada objek wisata ini nantinya akan memberi manfaat bagi pengembangan ekonomi lokal di daerah ini.
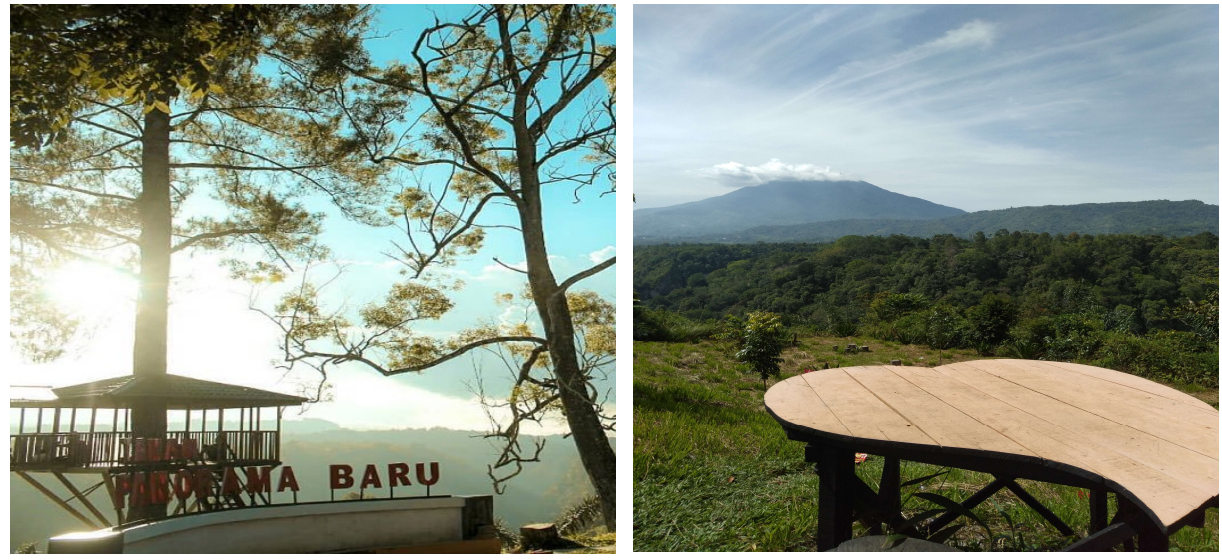

Gambar 5. Taman Panorama Baru

Sumber : Dokumentasi Pribadi, 2019

2) Ngarai Panorama Baru

Ngarai Panorama Baru merupakan kekayaan alam yang masih sangat alami dan jarang terjamah oleh tangan-tangan manusia di daerah ini. Menurut cerita masyarakat setempat dahulu ngarai ini merupakan tempat masyarakat mengambil air bersih untuk memenuhi kebutuhan sehari-hari namun sekarang sudah tidak ada lagi karena masyarakat lebih memilih untuk menampung air hujan atau membeli air bersih. Ngarai ini mempunyai aliran sungai yang berkelok-kelok sehingga tampak mempesona dan dikelilingi tebing hijau yang eksotik yang sangat indah. Aliran sungai di sini cukup deras karena merupakan pertemuan 3 sungai lain yaitu Ngarai Sianok, Ngarai Lambah dan Ngarai Panta. Selain sungai utama disekitar juga terdapat anak-anak sungai yang debit airnya bersifat musiman. Aliran sungai ini mengalir sampai ke daerah Agam seperti Nagari Sitingkai dan Lawang.

Selama ini potensi ngarai hanya sesekali saja dimanfaatkan masyarakat setempat. Pada tahun 2018 yang lalu ngarai ini sempat dijadikan salah satu rute lomba lintas alam wisata ke III dalam rangka memperingati hari olah raga nasional yang diadakan pemuda pemudi setempat. Kegiatan yang direncanakan jadi moment tahunan ini cukup sukses dan diikuti oleh 75 orang peserta yang berasal dari kalangan umum, pelajar mahasiswa dari berbagai daerah seperti Bukittinggi, Agam, Payakumbuh dan Padang Panjang. Selain itu pada hari Minggu ngarai ini juga sering dijadikan sebagai titik awal lintas alam ke arah hulu yaitu Ngarai Sianok oleh komunitas pencinta alam. 

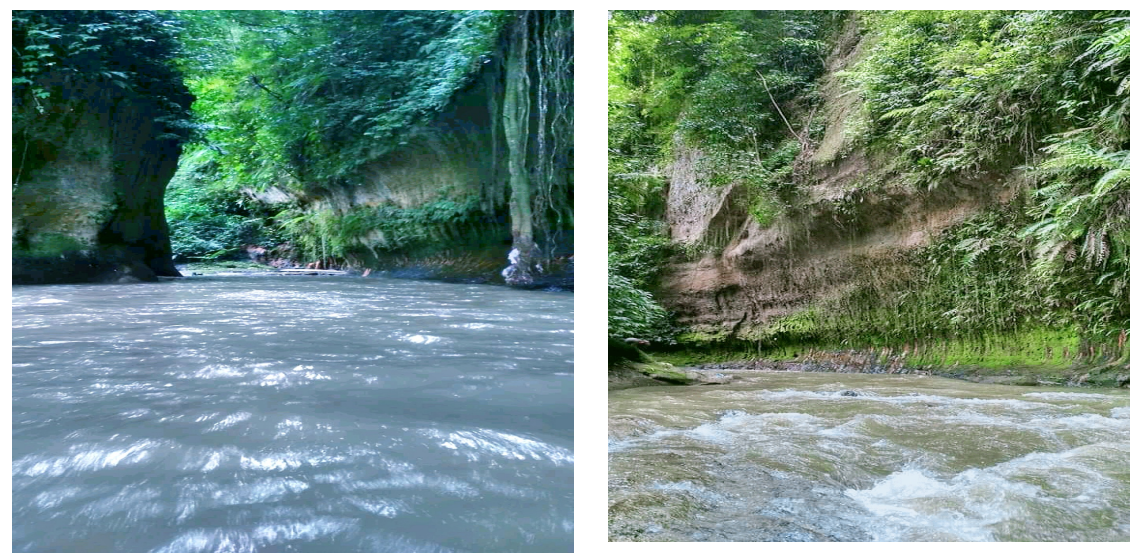

Gambar 6. Ngarai Panorama Baru

Sumber : Dokumentasi Masyarakat Lokal, 2019

Kondisi dan keindahan alam ngarai ini cukup potensial untuk dapat dikembangkan menjadi daya tarik wisata. Upaya pengembangan yang dapat dilakukan antara lain dengan lebih sering mengadakan acara-acara lintas alam sebagai sarana promosi wisata sekaligus mempelopori kegiatan-kegiatan dalam rangka menjaga lingkungan dan kelestarian alam. Sebagai daya tarik lain, di ngarai ini juga bisa dikembangkan atraksi wisata yang mengiurkan bagi penyuka wahana adrenalin seperti turbing, body rafting bisa juga bermain kayak. Dengan begitu kegiatan ini akan banyak melibatkan masyarakat sehingga bisa menjadi salah satu peluang menambah lapangan kerja baru dan menambah pendapatan masyarakat setempat.

B. Agrowisata

1) Agrowisata Indosiar

Agrowisata Indosiar merupakan satu-satunya agrowisata di Kota Bukittinggi. Objek wisata ini mulai dibuka untuk umum pada tahun 2008. Saat ini agrowisata ini telah cukup dikenal dan banyak dikunjungi wisatawan khususnya oleh anak-anak Taman KanakKanak dilingkungan Kota Bukittinggi dan Agam. Menurut pengelola rata-rata agrowisata ini dikunjungi 5 sekolah dan lebih kurang 50 keluarga/kelompok wisatawan setiap bulannya. Wisatawan yang berkunjung tidak hanya dari dalam daerah bahkan ada yang berasal dari luar negeri seperti Malaysia, Filiphina, Vietnam, Laos dll.

Di sini terdapat berbagai macam jenis tanaman seperti Salak, Jagung, Buah Naga, Durian Montong dll. Di agrowisata ini pengunjung ditawarkan berkeliling perkebunan untuk menyaksikan pemandangan alam yang indah karena berada tepat disisi ngarai Panorama, selain itu mereka bisa mengikuti rangkaian kegiatan wisata edukasi seperti 
pengenalan jenis tanaman, tata cara pembudidayaan tanaman dan lain-lain. Upaya pengembangan yang dapat dilakukan adalah dengan membangun sarana prasarana pendukung seperti spot foto, pusat kuliner, mushola dan wc umum dll.
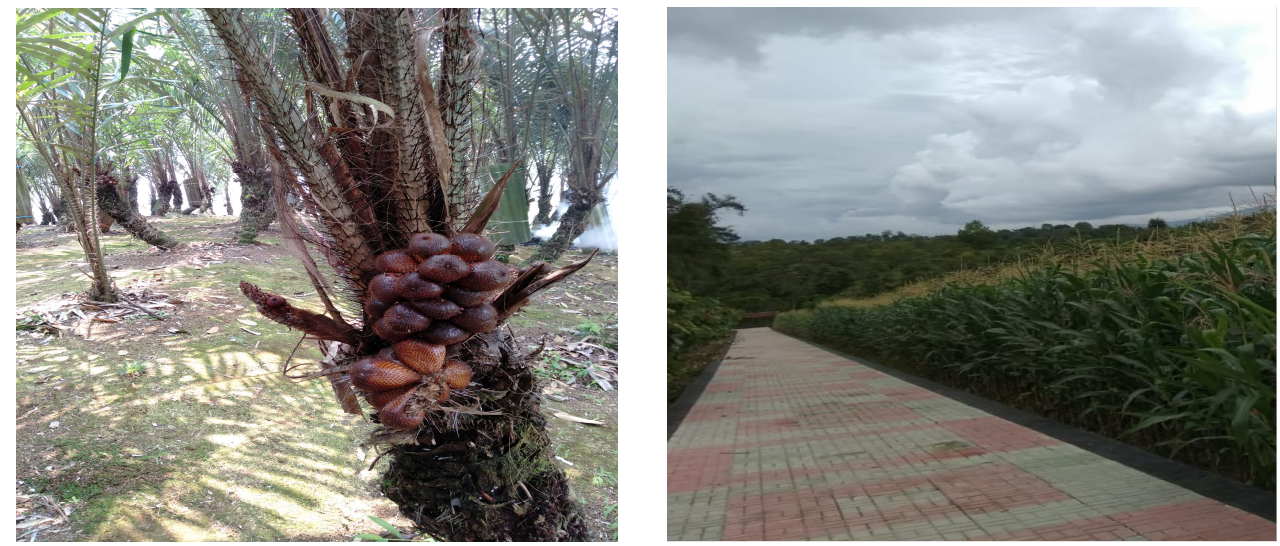

Gambar 7. Agrowisata Indosiar

Sumber: Dokumentasi Pribadi, 2019

2) Perkebunan Sayur dan buah-buahan.

Selain agrowisata Indosiar beberapa keluarga sudah membuka akses kebun salaknya untuk dikunjungi pembeli dengan langsung memetik sendiri ke pohon salaknya namun karena masih terbatasnya sumber daya yang ada, masyarakat belum bisa mengelola lahannya menjadi sebuah agrowisata sehingga untuk sekarang yang ada hanya sekedar membeli salak langsung ke kebun nya. Di daerah ini terdapat 2 jenis salak yang dikembangkan yaitu salak yang bibitnya berasal dari Medan dan Pondoh. Selain itu potensi pertanian lain yang bisa dikembangkan adalah perkebunan kopi, durian, pisang, jeruk dan banyak lagi buah-buahan dan tanaman sayuran lainnya.

Pengembangan juga bisa dilakukan dengan menawarkan beberapa aktivitas di area perkebunan seperti membakar jagung hasil pertanian dan memetik hasil kebun lainnya. Ketika musim durian, wisatawan juga bisa ditawarkan wisata berkemah sambil menunggui durian jatuh dari pohonnya.

3) Budidaya tanaman hias

Di daerah ini juga banyak terdapat budidaya tanaman hias milik masyarakat setempat. Budidaya tanaman ini ada yang merupakan kelompok tani ada juga yang merupakan milik pribadi masyarakat. Jenis tanaman hias yang ditawarkan juga beragam mulai dari angrek, anyelir, kaktus dan jenis tanaman hias lainnya. Tanaman hias juga banyak digunakan sebagai pelengkap dekorasi taman, kantor maupun rumah. Selain itu 
limbah tanaman seperti daun bisa diolah menjadi pupuk kompos yang aman digunakan untuk lingkungan.
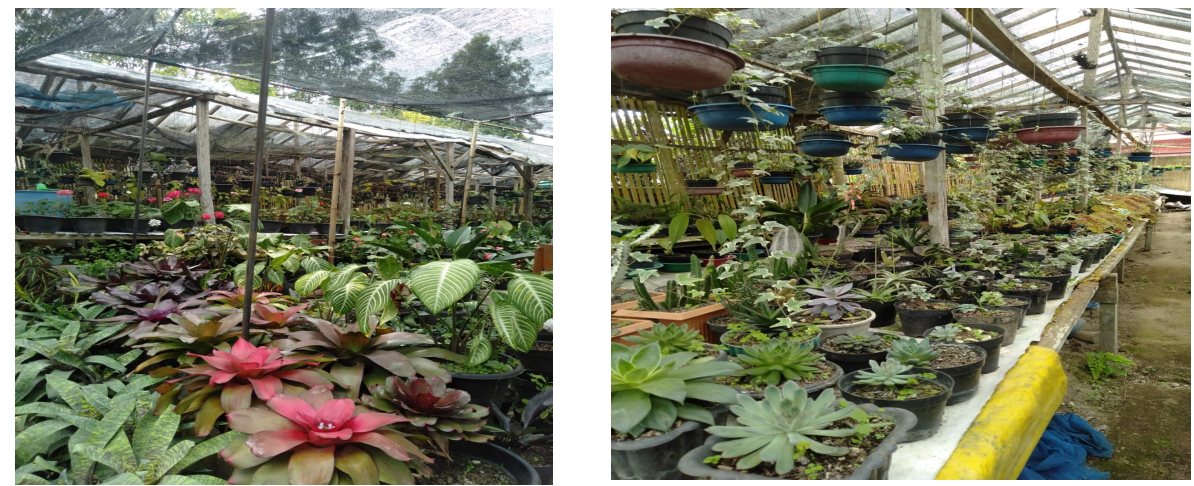

Gambar 8. Budi daya Tanaman Hias di Kampung Kuriman Panorama Baru Sumber : Dokumentasi Pribadi, 2019

\section{4) Peternakan Kelinci}

Di Panorama Baru sendiri terdapat 5 buah peternakan kelinci milik masyarakat. Peternakan yang paling besar memiliki 50 ekor induk kelinci dan puluhan ekor anaknya. Selama ini kelinci hanya dikembangbiakan untuk kemudian anak kelinci dijual kembali, padahal jika dikelola dengan baik, peternakan kelinci bisa menjadi daya tarik wisata di daerah ini. Upaya pengembangan agar potensi peternakan kelinci ini bisa dijadikan objek wisata antara lain dengan menata kandang kelinci menjadi lebih menarik. Selain itu bisa juga ditawarkan aktivitas seperti memberi makan kelinci, berfoto dengan kelinci dan wisata edukasi seperti cara perawatan kelinci yang baik.
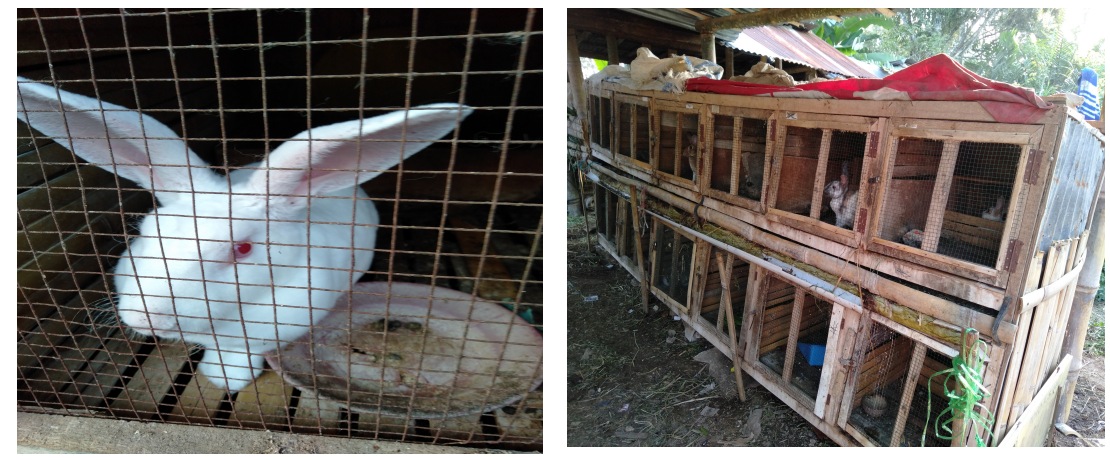

Gambar 9. Peternakan Kelinci di Kampung Kuriman Panorama Baru Sumber : Dokumentasi Pribadi, 2019

5) Peternakan Sapi

Sapi menjadi ternak yang banyak dikembang biakan masyarakat Panorama Baru. Berdasarkan data dinas Pertanian akumulasi jumlah sapi milik masyarakat di Kelurahan Puhun Pintu Kabun adalah sebanyak \pm 72 ekor dan di Kampung Kuriman ini terdapat lokasi peternakan sapi yang terbesar. 
Pengembangan usaha ternak sapi sangat menguntungkan guna pemenuhan kebutuhan akan protein hewani bagi masyarakat kota Bukittinggi. Selain itu di daerah ini juga terdapat usaha pembuatan pupuk yang berasal dari kotoran hewan yang telah dicampur dengan bahan lainnya sehingga menjadi pupuk kandang non kimia yang baik untuk tanaman dan lingkungan. Pupuk kandang ini baru bisa dipasarkan di kawasan Kota Bukittinggi dan sekitarnya karena produksinya masih dalam skala kecil.

Peternakan sapi ini mempunyai potensi untuk dikembangkan menjadi agrowisata. Disini bisa dijadikan tempat pembelajaran pembuatan sampah kompos dari kotoran ternak dan objek ini menjadi satu-satunya di Kota Bukittinggi.
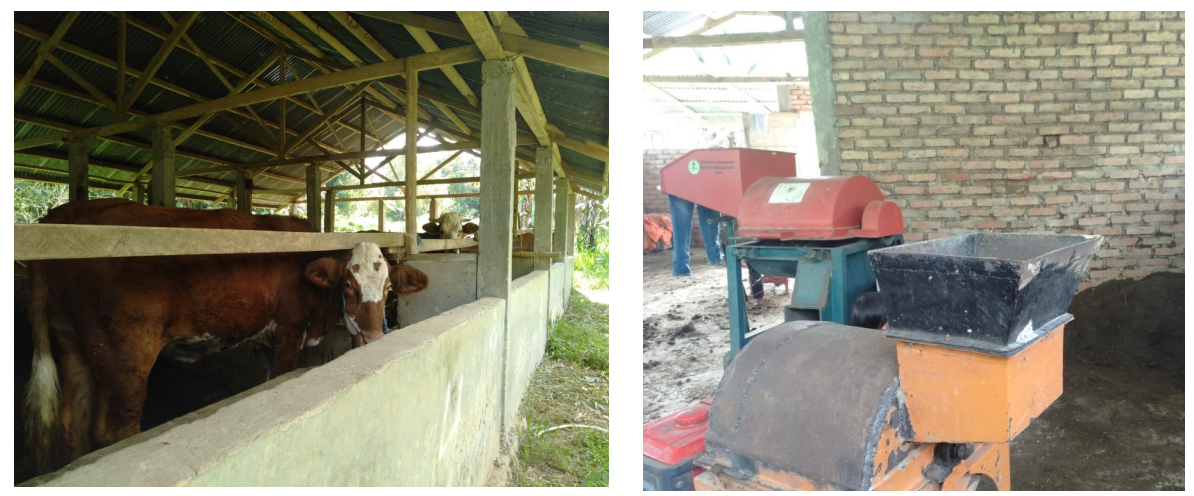

Gambar 10. Peternakan Sapi dan Proses Pengolahan Pupuk Kompos di Panorama Baru Sumber: Dokumentasi Pribadi, 2019

6) Peternakan Kambing

Selain kelinci dan sapi di Panorama Baru ini juga terdapat \pm 50 ekor kambing yang merupakan akumulasi jumlah ternak kambing milik masyarakat di kelurahan ini. Salah satu peternakan kambing dikelola oleh kelompok tani kambing perah dengan nama kelompok "Jam Gadang". Pada peternakan ini terdapat 25 ekor kambing namun hanya 11 ekor yang menghasilkan susu perah. Kapasitas produksi susu yang dihasilkan \pm 10 liter perminggu dengan dan dipasarkan di daerah Panorama Baru tersebut.

Peternakan kambing ini bisa dijadikan salah satu daya tarik agrowisata. Disini bisa ditawarkan wisata edukasi seperti mempelajari manfaat mengkonsumsi susu kambing dan aktivitas wisata seperti cara memerah susu kamping, proses pengolahan dan pengemasan. Upaya pengembangan dapat dilakukan dengan menambah jumlah kambing yang diternakan agar jumlah susu yang dihasilkan juga bisa meningkat. Lebih lanjut juga bisa dikembangkan pengolahan untuk susu kambing, bukan hanya untuk susu segar tapi bisa diolah menjadi varian keju, yogurt dan produk yang berasal dari susu kambing lainnya. 

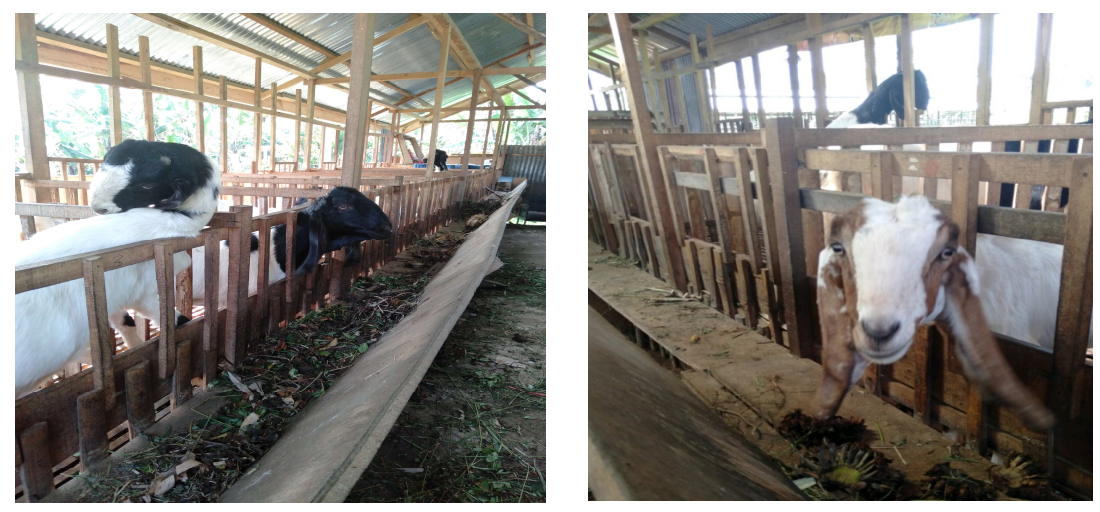

Gambar 11. Peternakan Kambing di Kampung Kuriman Panorama Baru Sumber : Dokumentasi Pribadi, 2109

C. Pertunjukan seni dan budaya

Masyarakat Panorama Baru masih mempertahankan kesenian budaya asli Minang "Saluang" dan permainan "KIM". Kesenian ini diadakan pada momen tertentu seperti dalam rangka memperingati ulang tahun Kota Bukittinggi dan dihadiri oleh puluhan masyarakat lokal dan juga masyarakat disekitar Panorama Baru. Panorama Baru juga mempunyai kelompok kesenian yang bernama "Pandendang Nagari". Menurut salah seorang pengurus kampung, kelompok kesenian ini sebenarnya sudah lama dibentuk namun baru aktif kembali pada awal tahun 2019 dengan beranggotakan lebih kurang 35 orang yang merupakan pemuda pemudi setempat. Anggota kelompok dilatih kesenian randai, silek tuo dan tarian tradisional Minangkabau dengan jadwal latihan satu kali seminggu dan berlokasi di Taman Panorama Baru.

Kesenian dan budaya ini merupakan potensi yang kuat untuk pasar wisata. Apalagi kesenian yang dikembangkan merupakan kesenian dan budaya tradisional yang sudah mulai langka di Minangkabau. Upaya pengembangkan yang perlu dilakukan salah satunya dengan memfasilitasi kelompok seni dengan peralatan kesenian yang lebih lengkap sebab menurut narasumber saat ini pengembangan terkendala dengan keterbatasan dana untuk peralatan. Saat ini saja setiap latihan hanya memakai tape dan kaset karena belum punya peralatan musik. Selanjutnya bisa dilakukan pementasan seni di lokasi wisata seperti Taman Panorama Baru yang bisa dijadikan sarana promosi wisata. Dengan adanya pertunjukkan seni dan budaya ini maka akan menarik wisatawan yang berkunjung sehingga bisa menghidupkan perekonomian masyarakat lokal. 

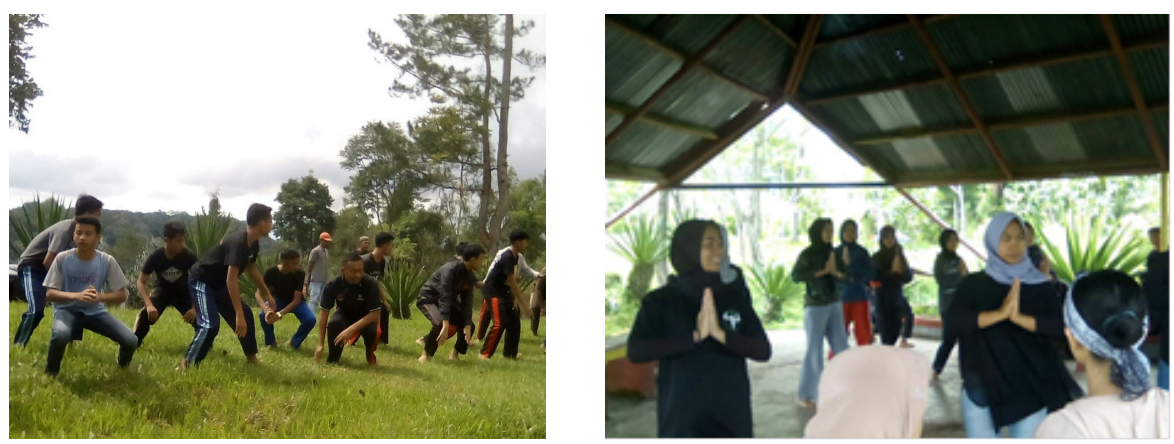

Gambar 12. Latihan Randai dan Tari Tradisional oleh kelompok Seni Padendang Nagari di Taman Panorama Baru

Sumber: Dokumentasi masyarakat lokal, 2019

Di Kampung Kuriman juga terdapat industri pengolahan hasil pertanian menjadi beberapa jenis jajanan tradisional yang merupakan ciri khas dari Minangkabau. Jajanan tersebut antara lain : lapek pisang, lapek ubi, kacimuih, lopih, ripik dll. Saat ini produksi jajanan tersebut hanya bersifat usaha rumah tangga dan dipasarkan dengan skala kecil di pasar-pasar tradisional yang ada di Kota Bukittinggi. Hal ini dapat berpotensi untuk dikembangkan menjadi wisata kuliner di Panorama Baru. Industri kuliner ini bisa dijadikan tempat pembelajaran dalam rangkaian kegiatan agro yang menawarkan bagaimana mengolah hasil pertanian menjadi makanan. Dengan dikembangkannya aktivitas ini maka juga dapat dijadikan sarana promosi sekaligus pelestarian kearifan lokal dibidang kuliner.

D. Wisata Aktivitas dan Edukasi

1) Rumah Sehat dan Taman Bacaan Mutiara Hati

Di Panorama Baru juga telah terdapat rumah edukasi yaitu Rumah Sehat dan Taman Bacaan Mutiara hati. Pemilik rumah menghiasi pekarangan rumahnya dengan tanaman-tanaman hias dan tanaman obat dengan menggunakan barang bekas yang didaur ulang seperti ban bekas untuk pot tanaman. Selain itu di rumah sehat ini juga dilengkapi dengan taman bacaan. Konsep rumah sehat dan taman bacaan dengan berbagai aktifitas edukasi menjadi pelopor di daerah Sumatera Barat. Pengunjung yang datang berasal dari berbagai daerah bahkan berbagai negara ditawarkan wisata edukasi seperti pengenalan tanaman, manfaat tanaman, pengolahan hasil tanaman, dll. Setiap hari Minggu juga diadakan program edukasi "Warung Inggris" yang mana anak-anak di lingkungan sekitar diajarkan berkomunikasi dengan wisatawan asing yang berkunjung tentang berbagai hal yang terkait dengan lingkungan. 

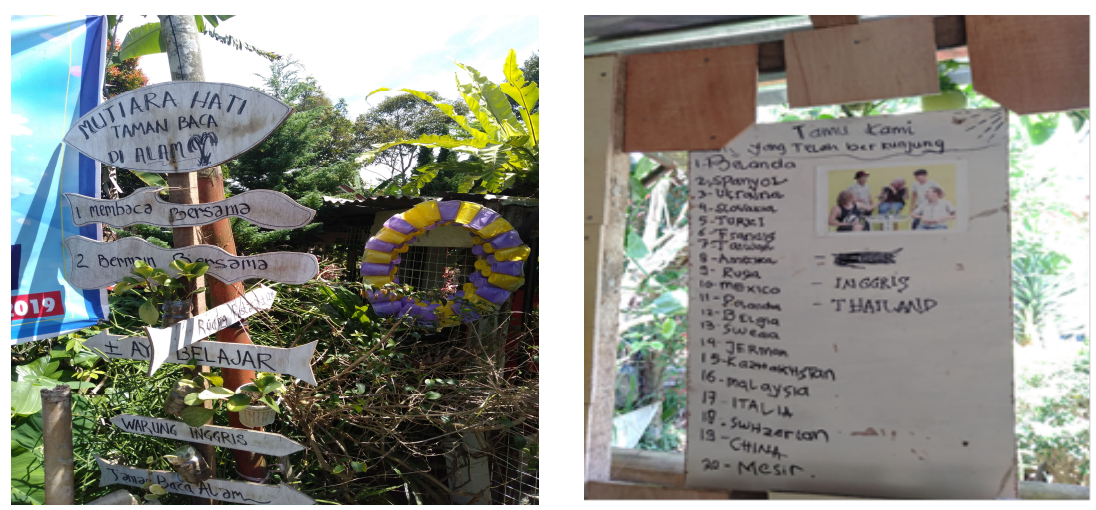

Gambar 13. Rumah Sehat dan Taman Bacaan Mutiara Hati Sumber : Dokumentasi Pribadi, 2019

\section{2) Buru Babi}

Aktivitas wisata yang telah dikembangkan di Panorama Baru adalah wisata "Baburu Babi". Wisata Berburu Babi awalnya hanya kegiatan yang dilakukan petani dan masyarakat Panorama Baru dalam rangka membasmi hama babi yang mengganggu pertanian di daerah Panorama Baru. Dalam 2 tahun terakhir buru babi ini telah menjadi kegiatan wisata yang dilakukan secara besar-besaran sebanyak 2 kali setahun dan diikuti oleh ratusan bahkan mencapai ribuan peserta yang berasal dari Sumbar, Riau dan Jambi. Kegiatan ini sangat potensial untuk menjadi daya tarik wisata karena mengundang massa untuk datang ke Panorama Baru. Kondisi ini bisa menjadi peluang menambah penghasilan masyarakat dengan berdagang sekaligus menjadi sarana promosi wisata di Panorama Baru.
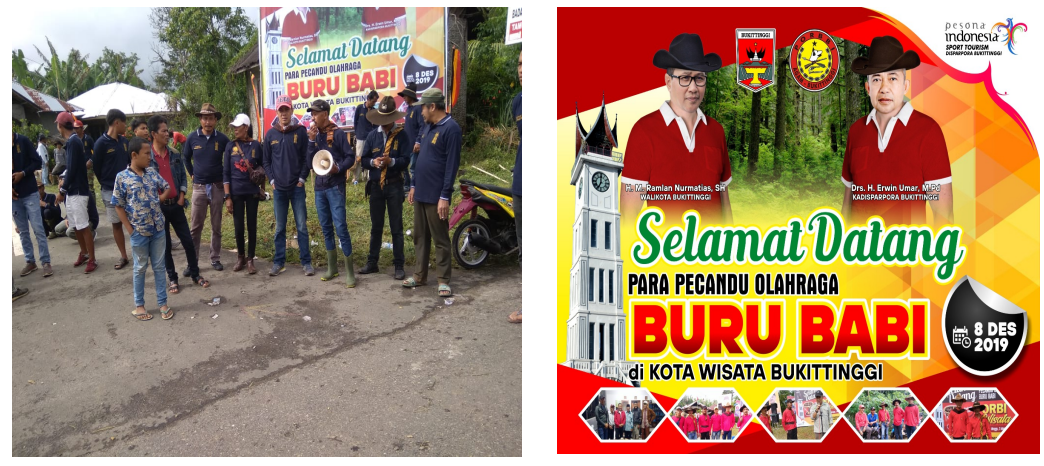

Gambar 14. Buru Babi Wisata di Kampung Kuriman Panorama Baru Sumber: Dokumentasi masyarakat lokal, 2019

Panorama Baru mempunyai paket yang lengkap sebagai daya tarik agrowisata namun dalam pengembangannya belum didukung oleh kerjasama yang baik dari seluruh pihak yang berkepentingan seperti pemerintah dan masyarakat lokal. Dari sisi pemerintah saat ini hanya menetapkan daerah tersebut sebagai ruang terbuka hijau dan taman kota 
Jurnal Planologi Vol. 17 No. 1, April 2020

yang menjadi arahan untuk agrowisata tanpa ada program pengembangan lebih lanjut. Selain dari Pemerintah, kendala juga bersumber dari masyakat itu sendiri. Saat ini sebagian masyarakat Panorama Baru masih mempunyai pemikiran yang salah tentang agrowisata. Masyarakat beranggapan bahwa dengan adanya agrowisata bisa membuat mereka kehilangan hak atas lahan pertaniannya, selain itu banyak wisatawan asing yang berkunjung dianggap bisa merusak kebudayaan mereka.

Kebijakan yang dapat dilakukan untuk mengatasi masalah diatas adalah mengarahkan pengembangan agrowisata di daerah ini dengan konsep berbasis masyarakat atau dikenal juga dengan istilah Communities Based Tourism (CBT). Konsep CBT menjadi arahan yang tepat mengingat semua objek wisata baik yang sudah dikembangkan maupun yang masih potensial berada ditanah ulayat masyarakat. Dengan konsep ini masyarakat sebagai pelaku utama dalam pembangunan baik sebagai perencana, investor, pelaksana, pengelola, pemantau maupun evaluator. Brian Furze dalam Noer (2006) juga menjelaskan bahwa sebuah model pembangunan berbasis lokal yang memerlukan pengambilan keputusan baik dalam tahap perencanaan dan implementasi kegiatan paling baik dilakukan oleh masyarakat lokal itu sendiri. Walaupun begitu selain peran masyarakat setempat, dalam pengembangan daerah ini menjadi kawasan agrowisata juga tidak lepas dari campur tangan Pemerintah apalagi saat ini dari modal sumber daya manusia yang mempunyai kompetensi dibidang pariwisata untuk daerah ini masih sangat minim.

\section{KESIMPULAN DAN SARAN}

\subsection{Kesimpulan}

Berdasarkan hasil analisis daerah berdasarkan berbagai aspek di Panorama Baru menunjukkan bahwa daerah Panorama Baru mempunyai karakter dan potensi wisata yang lengkap untuk pengembangan agrowisata. Hanya saja masih diperlukan banyak pembenahan untuk dapat mencapai pembangunan agrowisata yang membawa manfaat bagi pengembangan ekonomi lokal terutama dari aspek kelembagaan dan pembangunan sarana dan prasarana.

Untuk perencanaan pembangunan diarahkan berbasis masyarakat karena saat ini semua objek berada di tanah masyarakat dan ulayat. Namun terkait hal tersebut mengingat masih sangat terbatasnya sumber daya manusia yang kompeten dibidang pariwisata, peranan Pemerintah sangat diperlukan dalam menetapkan peraturan, perencanaan serta 
kajian lebih lanjut berkaitan dengan pengembangan agrowisata di Panorama Baru bersama dengan masyarakat.

\subsection{Saran}

Dari hasil analisis dapat disimpulkan bahwa pengembangan agrowisata membutuhkan dukungan serius dari pemerintah, stakeholder dan masyarakat setempat. Implikasi kebijakan yang diperlukan agar agrowisata dapat bermanfaat bagi pengembangan ekonomi masyarakat lokal antara lain:

A. Menyusun peraturan, perencanaan strategis, dan kajian lebih lanjut terkait dengan pengembangan agrowisata di Panorama Baru.

B. Meningkatkan kapasitas sumber daya manusia pelaku pariwisata

C. Meningkatkan program pembangunan wisata berbasis pemberdayaan masyarakat

D. Mengembangkan daya tarik wisata dan objek wisata baru

E. Meningkatkan kualitas pelayanan wisata di Panorama Baru

F. Menyediakan dan memfasilitasi pengembangan sarana prasaranautama dan pendukung bagi agrowisata di Panorama Baru

G. Meningkatkan promosi tentang objek wisata dan agrowisata di Panorama Baru.

\section{DAFTAR PUSTAKA}

Amelia, R. (2012). Analisis Peranan Subsektor Industri PariwisataTerhadap Perekonomian di Kota Bukittinggi Tahun 2006 -2010 (Thesis). Padang: Program Pasca Sarjana Universitas Andalas. hl 118.

Andereck, L.; Valentine M.; Knopf C. and Vogt A. (2005). Residents' Perception on Community Tourism Impacts. Annals of Tourism Research, 32 (4), 267-282.

Aulya, R., Mindarti, L.I.,and Amin, F. (2016). Strengthening Local Economy Through Community Based Tourism in Governance Perspective. Ad'ministrare, 3 (2), 1130 .

Blakely, E. (1994). Planning Local Economic Development (Theory and Practice). California: Sage Publication. hl 446 .

BPS. (2019). Bukittinggi Dalam Angka 2019. Bukittinggi, 399 hal: BPS.

Budiarti, S. (2013). Pengembangan Agrowisata berbasis Masyarakat pada Usaha Tani Terpadu Guna Meningkatan Kesejahteraan Petani dan Keberlanjutan Sistem Pertanian. Jurnal Ilmu Pertanian Indonesia, 18 (3), 200-207. 
Kementerian Pariwisata, Kementerian Desa. (2015). Buku Panduan Pengembangan Desa Wisata Hijau. Jakarta: Kementerian Koperasi dan UKM. 68 hal

Jaafar, M., Kayat, K., Tangit, T. M.,and Yacob, M. F. (2013). Nature-based rural tourism and its economic benefits: A case study of Kinabalu National Park. Worldwide Hospitality and Tourism Themes, 5 (4), 342-352.

Juwita, A.R., Rahmafitria, F,. dan Rosita. (2017). Pengaruh Persepsi Masyarakat terhadap Pengembangan Desa Wisata Ciburial Kabupaten Bandung. Torism Scientifis Journal, 3 (1),1-15.

Karampela S , Papapanos G and Kizos T. (2019). Perceptions of Agritourism and Cooperation : Comparisons between an Island and a Mountain Region in Greece. Sustainability Journal, 11 (1), 680-698.

Badan Keuangan (2018). Laporan Keuangan. Bukittinggi: Pemerintah Kota Bukittinggi. Munir, R. (2017). Pengembangan Ekonomi Lokal Partisipatif: Masalah, kebijakan dan Panduan Pelaksanaan Kegiatan. Jakarta: Local Governance Support Program (LGSP). Hal 174.

Noer, M. (2006). Pembangunan berbasis kelembagaan adat: Sebuah alternatif pembelajaran dari kasus kinerja kelembagaan nagari dalam perencanaan wilayah di propinsi Sumatera Barat. Mimbar : Jurnal Sosial dan Pembangunan, 12 (2), 234 257.

Nurhidayati, S. E. (2013). Pengembangan Agrowisata Berkelanjutan Berbasis Komunitas Di Kota Batu, Malang (Ringkasan Disertasi). Yogyakarta: Universitas Gajah Mada. hl 32.

Puspito, A. R. and Rahmawati, D. (2015). Faktor-Faktor yang Berpengaruh terhadap Pengembangan Kawasan Agrowisata melalui Pendekatan Community Based Tourism di Kecamatan Bumiaji Kota Batu. Jurnal Teknik ITS, 4 (2), 92-97.

Sastrayuda, G. (2010). Konsep Pengembangan Kawasan Agrowisata Hand Out Mata Kuliah Concept Resort And Leisure, Strategi Pengembangan dan Pengelolaan Resort And Leisure. Retrieved from UPI Website: http://file.upi.edu.gumelar_s.go.id.(diakses 20 November 2019) 